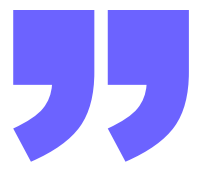

\title{
ANALYSIS OF COMMAND, ORDER, AND REQUEST DIRECTIVE SPEECH ACT FOUND IN FROZEN 2 MOVIE
}

\author{
Ni Kadek Windra Yani ${ }^{1}$, Putu Devi Maharani ${ }^{2}$ \\ Mahasaraswati Denpasar University, Indonesia ${ }^{12}$ \\ windrayani2299@gmail.com, \\ devmaharani86@gmail.com,
}

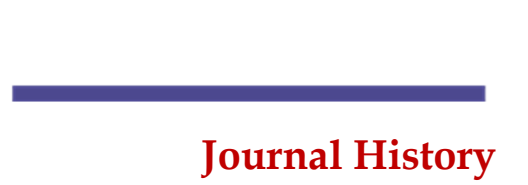

Submitted 14th December 2021

Revised 12 th January 2022

Accepted 15th January 2022

Published 24 $4^{\text {th }}$ January 2022

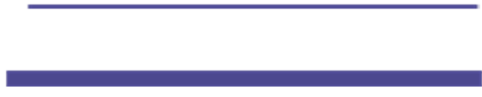

Keywords:

Directive, speech acts, frozen2 movie.

\begin{abstract}
Being a social human, people have a way to express their hopes, which produces a directive illocutionary act. Directive illocutionary acts are a fascinating phenomenon of illocutionary acts. This research used theory from Searle (1979) to find out the dominant three types of directive speech act, Leech theory (1983) about Aspect of Speech theory to analyze the purpose of directive speech acts. The researcher used a descriptive qualitative approach to collect data, the data that are founds from the data source were analyzed by using formal and informal method to support the research. According to the findings of this study, there are three types of directive speech acts used by figures in Frozen 2 Movie, they are command (76\%), order $(11 \%)$, request $(13 \%)$. The three dominant types have quite similar meaning but in this research the researcher try to analyze and find out their differences clearly.
\end{abstract}




\section{INTRODUCTION}

According Humans for the most part live in societies with other people. They converse with one another in their daily activities to form relationships in their social lives, which also involves interaction through language. Sapir (1921: 2) Language is one of the most important aspects of communication in our daily lives since it allows the speaker and listener to exchange information. When it comes to communication, there are two options its can be direct and indirect. We can make the listener do anything or behave based on our attention when we say something. Actions performed via utterance are generally calls Speech Acts. It requires much more than a sense of the words uttered and the grammatical relationship between them in the interpretation of an utterance.

Searle (1979: 13) directive speech acts is the illocutionary point of these consists in the fact that they are attempts (of varying degrees, hence, more precisely, the speaker decides the determinable thing that entails trying to get the listener to do something. Searle (1979: 13) divided directive speech acts as five classifications of illocutionary act namely (1) Advice, (2) Command, (3) Order, (4) Question, (5) request. In this study the researcher focused to analyze the three dominant types of directive speech act such as command, order, and request because three of them have a similar meaning. Command is produced by a sentence that normally have not a clear grammatical subject it can be happened when the speakers telling the hearer doing something that can't be stopping (Searle, 1979). The sentence of command is usually followed by exclamation mark. Order is one of directive speech acts which aim to make listener do something directly which is done (Searle, 1979). In order the speaker has an authority when tell someone doing something and the sentences of order only contain a statement without command sentence. Request is the last of directive speech which is have purpose to asking something from the hearer in the situation, in request the utterance more be politely (Searle, 1979). The sentence structure in request usually contains please, may, can, could, will you, so that request also using form of question because in request the speaker ask permission or agreement before telling the listener to do something.

Based on Leech (1983: 13) In order to know the purpose of the utterance there are five aspects in every situation of speech that can be used to analyzing the purpose of an utterance or conversation in the movie, they are: addressers or addressees, the context of an utterance, the goal of an utterance, the utterance as a type of a speech act or action, speech because of a verbal act. Addressers or addressees mean the speaker who utter the utterance. The context of an utterance is some aspects of the 
physical or social setting of an utterance. The goal of an utterance is to know and talking about the important meaning or speaker want in deliver utterance. The utterance as a type of a speech act or action is when a grammar has a relation with abstract static entities such as sentence (in syntax) and preposition in (in semantics) that can be affect the utterance. Speech because of a verbal act is can be used of a verbal act rather than using verbal act itself as an expression, question, or spoken with polite rising intonation as a submission in the utterance.

The researcher would like to present six researchers from the previous study that were analyze similar things in terms of directive speech acts. The first study was done by Ariyasa (2020) with entitled $A n$ Analysis of Directives Illocutionary Act Found in Ride Along Movie. The aims of this study are to classify the kinds of directives illocutionary acts used by the characters in Ride Along movie and to analyze the meaning of directives illocutionary act expressed by the characters in Ride Along movie. The theory that he used is proposed by Yule (1996:54). The second study written by Alexander (2019) entitled Expressive Speech Acts in the Hotel Transylvania Movie. This study analyzed types of expressive speech acts spoken by the characters on dialogue and find out the function of the speech act in Hotel Transylvania movie. This study uses theory that proposed Leech (1983: 104) and Yule (1996:51) to answer the problem that mentioned above. The third study is entitled An Analysis of Expressive Illocutionary Acts Found in The Light Between Ocean Movie Script by Margaretha (2018). To identify the type of illocutionary act used with the main character in the Light Between Ocean Movie Script and to analyze the purpose of the illocutionary act in the utterance of the main character in the movie Light Between Ocean are the aims of this study. Theory that proposed by Austin (1962) was used to analyze the data. Fourth, research by Fara Della (2018) with entitled An Analysis of Directive Speech Acts by Searle Theory in "Sleeping Beauty" Movie Script. The aims of this study were to find out the types of directive speech acts by the character in "Sleeping Beauty" movie script based on the theory that proposed by Searle theory and analyze the type of directive speech acts that most frequently used in the movie script and the possible reason. The theory proposed by Searle (1979) was use in this study to analyze the data.

The Fifth study is entitled An Analysis of Directive Speech Acts in The Fault Stars Movie Script that written by Febi Rosella Wijaya \& Jauhar Helmie (2019). The aims of this study are identifying the directive speech acts performed in "The Fault Stars" movie script and investigated how often the directive speech acts performed and which type of directive speech act that are most frequently used in the movie script. This study used theory proposed by Yule (1996). The sixth research with entitled Illocutionary Act In The Main Characters Utterances in Mirror Mirror Movie by Fita Nur Rahayu, M.Bahri Arifin, Setya Ariani (2018). They found out the 
types of illocutionary act and found the context of underlying illocutionary act of the main character by Hymes' speaking model in Mirror Mirror movie with using theory proposed by Wardaugh (2006) and Yule (1996). Directive speech acts are an element of pragmatics, which is the study of how linguistic signs, words, and sentences are used to convey meaning. According to Gerson \& Paulman (2019:4) Directive is communications play a critical role in infants' and young children's daily routines as they are regularly guided by close others. Directive speech acts tells the readers that speech acts are not only available in a daily conversation but also can find in a song and movie which are very interesting to analyzed because movie and song have close relationship with our daily life. This study aims at identifying kinds of directive speech acts and analyzed the purpose of the utterance delivered by the characters in the Frozen 2 Movie

\section{METHODS}

The data for this analysis was taken from the Frozen 2 movie. The data were collected from the utterance of a few main characters in the movie, they are: King Leunard, King Agnarr, Queen Iduna, Elsa, Anna, Kristoff, Olaf, Pabbie. The data were collected through observation method by watching the movie repeatedly. The data were classified into the three dominant types of directive speech acts such as: command, order, and request. The data was analyzed qualitatively by using theory from Searle (1979: 13) to identify the three dominant types of directive speech acts and theory from Leech (1983: 13) to analyze the purpose of utterance through aspect of speech. The data were presented in formal and informal method.

\section{RESULTS AND DISCUSSION}

\section{RESULTS}

This part presents the findings of the study, which is provided in a table that displays the number of occurrences as well as the percentage of usage of the stated utterance, as well as a discussion of each kind based on the utterances identified in the data source.

Table 1. Illocutionary Act Found

\begin{tabular}{c|ccc} 
No & $\begin{array}{c}\text { Types of } \\
\text { Directive } \\
\text { Speech Acts }\end{array}$ & $\begin{array}{c}\text { Number of } \\
\text { Occurrences }\end{array}$ & Percentage \\
\hline 1 & Command & 28 & $76 \%$ \\
\hline 2 & Order & 4 & $11 \%$ \\
\hline 3 & Request & 5 & $13 \%$ \\
\hline Total & & 37 & $\mathbf{1 0 0} \%$
\end{tabular}


The result of this study shows that there were three types of directive speech acts dominantly used by the character in the Frozen 2 movie, they are command, order, and request. The three dominant types of directive speech acts have a specific meaning. In here command is the biggest percentage of the utterance by the character in Frozen 2 movie. That are used to demanding something for the hearer. Thirty-seven statements or utterances are the frequency of all utterances is $(37 \%)$. Command, order, and request is accompanied by the occurrence of twenty-eight utterances $(76 \%)$, four utterances $(11 \%)$, five utterances $(13 \%)$. The following section explains the three dominant types of directive speech acts as well as its functions. In the discussion, only 6 examples are offered in the three dominant types such as command, order, and request.

\section{DISCUSSION}

Directive speech acts is part of illocutionary that make the hearer do something and an act that appear from utterance delivered by the speaker to make the hearer change the situation. According to Searle (1979:13) Speech Act is the basic or minimal units of linguistic communication. The three-dominant type of directive speech act will be explained by analyzing the utterance of the three dominant types in accordance with the aspect of speech.

\section{Command}

The second type of directive speech act is a command. Command directive speech act is the utterance in which the speaker tells the listener to do something through an utterance that lacks a clear grammatical subject. In the Frozen 2 movie, 28 utterances categorized as command are found. The two examples are explained as follows:

\section{Data 1}

Anna : Come on! You definitely look disturbed.

Elsa : I think I'll turn in.

(Frozen 2: 00:13:56)

Based on the theory of directive speech act Anna uttered an utterance that belongs to command and can be formed into imperative sentence because on the sentence structure there was verb one at the first sentence and followed by exclamation mark at the last sentence based on the theory command have not a clear grammatical structure. When Anna said, "Come. on! You definitely look disturbed" that utterances belong to give command for Elsa therefore that utterances have a specific purpose to make someone doing something immediately and cannot be refused to make Elsa quickly give a right answer to make their games clear. The conversation above shows between Anna and Elsa as a sibling, in this 
scene Anna as the speaker and Elsa as the hearer. The context of an utterance that uttered by Anna means she tried to give a command to Elsa because she looks Elsa spent too much time in confirming the clue in the game which guessed by Anna. Because of that the goal of utterance that uttered by Anna she wanted to give a command to answer Anna's guess and make sure it is correct or incorrect. The sentences that are used by Anna also indicated she wanted to give a command like when she said "Come on! You definitely look disturbed" it means she tried to give commands Anna's answer is right and do not think about it many times. The stressed intonation at the end of the sentences also delivered the message Anna tried to give a command to Elsa. According to analysis above the purpose of Anna uttering a command directive speech acts in the conversation because in their games Elsa as a clue giver cannot focuses and her face looks very worried sparing long time to hear Anna's answer so that Anna very confident in her answer and she couldn't wait to continue her turn as a clue giver.

\section{Data 2}

Anna : Help me stop Olaf!

Olaf : All right it's will be okay.

(Frozen 2: 00:57:34)

The conversation that contains an utterance above can be categorized as a command because based on the theory directive speech act command used to make someone doing something immediately and cannot be stopping, it also can be formed into imperative sentence because on the sentence structure there was verb one at the first sentence and followed by exclamation mark at the last sentence. Like the utterances above when Anna said "Help me stop Olaf" its mean Anna requiring Olaf to help her directly to stopping their movement at the ship. At the conversation they are a friendship, here Anna as the speaker and Olaf as the hearer. In this scene Anna feels really panic because her sister cursed their ship to go far away until she cannot control the magical ship as the context of utterance of this analysis. Therefore, the goal of the utterance that uttered by Anna is she wanted to give command to Olaf helping her to stop the ships. The words that were uttered by Anna used in the sentences also kind of command words like when she said "Help me stop Olaf" the sentence not has a clear grammatical to be an impolite utterance. It was support with rising intonation from Anna when uttered the utterance its mean Anna feeling worried about her condition in the ship. From the analysis above the purpose of Anna in uttering command directive speech acts in the conversation to make them ship that cursed by her sister stop quickly to find her sister who was face their mistake alone and wants to help her sister to solve all problem together. 


\section{Order}

The third type of directive speech is order. Order is a type of directive speech act that aims to get the listener to do something that must be done right away. In Frozen 2 movie, there are 4 utterances which categorized as order are found. The two example is explained as follows:

\section{Data 3}

Queen Iduna : Anna Elsa, bed time soon.

Anna, Elsa : Hoo...oo

(Frozen 2: 00:00:59)

This utterance is categorized as an order because based on the theory, the meaning of order is used to get the listener to do something that should be done cause the speaker has an authority tell someone do something. This utterance also can be formed into declarative sentence because the sentence used only contain statements without containing exclaim mark and command sentence. When Queen Iduna uttered an utterance "Anna Elsa, bed time soon" that means Queen Iduna has a rights to be a parents to make her daughters must sleep on time. In the conversation above between Queen Iduna, Anna and Elsa, they are mother and daughter. In this scene, Queen Iduna is as the speaker the Anna and Elsa are as the hearer. Queen Iduna uttered that utterance because the context of utterance here at night she saw Anna and Elsa still playing a snow together. Because of that the goals of the utterance by Queen Iduna she wants Anna and Elsa stop playing their snow games at night. From the sentences that Queen Iduna used also delivered the message she gave the order to do something like when he said "Anna Elsa, bed time soon" its mean he gave an order to Anna and Elsa the time has shown for bedtime and take a rest. The fall down intonation when Queen Iduna uttered that utterance also makes Anna and Elsa understand that is order words and they reply to give an action. From the analysis above the purpose of Queen Iduna in uttering order directive speech acts in the conversation because she very took care her children, she wants Anna and Elsa keep their health and reminds them that is already night to limit their play times and stopping their games so that they can rest well.

\section{Data 4}

Arrendele assistant : Your Majesty, they're ready.

Elsa :Ohhmm... Okay

(Frozen 2: 00:07:54)

The bold sentence in the utterance above is part of order that used by the speaker because the speaker has an authority to make someone 
doing something that must be done that written on the theory question directive speech acts. The utterance above only contains a statement without command sentence therefore it can be formed as declarative sentence. The example of the utterance that is uttered by Arrendele assistant when he meets Elsa in her queen room and said, "Your Majesty, they're ready." That utterances means Arrendele assistant has a right to make Elsa immediately went to the party hall to meet Arrendele resident because they have been waiting the queen of Arrendele so that Elsa must already be aware with the order utterance that uttered by her assistant and do it soon to meet her residents. In this scene Elsa is a queen of Arrendele as a hearer and her assistant as a speaker. He uttered that utterance because the context of utterance here Arrendele residents have come and gathered while waiting their queen at the spring party so that the goal of the utterance that uttered by Arrendele assistant is to make Elsa can immediately meet them. From the sentences that Arrendele assistant used also delivered the message he gave the order to do something to make Elsa get ready herself to welcoming her residents. The rising intonation when he uttered that utterance also makes Elsa understand that is order words and he reply to give an action and down the stairs to meet her residents soon. From the analysis above the purpose of Arrendele assistant uttered an order directive speech acts in the conversation above to make Elsa soon meet her residents who already complete gathered to start the summer party as a queen of Arrendele.

\section{Request}

The last type of directive speech act is request. Request is a type of utterance that is included in directive speech acts and is used to ask something from the listener in a politely ways. In Frozen 2 movie, there are 5 utterances which categorized as requests are found. The two examples are explained as follows:

\section{Data 5 \\ Kristoff Sven (Crow) : Sven, keep us steady, will you? \\ (Frozen 2: 00:24:39)}

This utterance is categorized as a request because based on the theory request directive speech acts used to ask something from the hearer politely then here the politeness utterance "Sven, keep us steady, will you?" that has a meaning before Kristoff told Sven to slow down the movement of the train, he asked permission first to confirm Sven ready or not to follow his request. In the conversation above between Kristoff and the crow named Sven who rides the train, in this scene Kristoff as the speaker and Sven as the hearer. The context of the utterance uttered by 
Kristoff means there is a beautiful night and all of his friend already sleep then he wants to make a sweet memory together with Anna. Because of that the goal of utterance uttered by Kristoff in the conversation above is she wants Sven to ride the train in balance slowly so that atmosphere feels peaceful. The sentences that are used by Kristoff also make Sven understand and doing an act. The stress intonation that is used by Kristoff at the last sentence when uttered "will you?" also makes Sven very happy to hear the utterance and it is the polite expression before ask someone doing something especially in request directive speech acts. From the analysis above the purpose of Kristoff uttered that utterance in the conversation because Kristoff and Anna are in a relationship. They always capture the moment wherever they are, so from that Kristoff uttered request directive speech acts for Sven to make their journey in the train be a memorable story.

\section{Data 6}

Anna : Please make sure they stay out of the kingdom until we return.

Pabbie : Yes, I will.

(Frozen 2: 00:22:34)

The conversation that contains an utterance above can be categorized as a request because based on the theory request directive speech acts used to ask something from the hearer politely same with the utterance above when Anna tried to give request with a politeness way and said "Please make sure they stay out of the kingdom until we return" its means Anna entreating Pabbie to took care Arrendele residents and make sure they live in a safer place. Anna is as the speaker and Pabbie is as the hearer in the conversation. They are best friend which meet in the forest 10 years ago and Pabbie know about everything. The context of the utterance that uttered by Anna means because she will go for a long time with her sister in Enchanted forest to solve a problem in the past of Arrendele, because of that the goal of the utterance that uttered by Anna to make Pabbie take care of her residents while they go away. The sentences that are used by Anna when she uses the word "Please" also make Sven understand she need a help with a politeness way and Sven agree to help her. The stressed intonation in the first sentence also delivered a message to give a request to Pabbie that Anna really need Pabbie's help. From the analysis above the purpose of Elsa in uttering request directive speech acts in the conversation above Anna and all of his family including Elsa as a queen of Arrendele will go in a long journey to fix the problem that are currently happening in Arrendele at the Enchanted forest from here Anna know she and her family can't take care the Arrendele residents when danger comes, so that Anna uttering request 
directive speech act for Pabbie to protect all of her residents from the dangers that often occur in Arrendele while they are go far away.

\section{CONCLUSION}

This study was focused to analyze the three dominant types and purpose of directive speech acts in the Frozen 2 movie in each conversation produced by the characters, using aspects of speech. There are 37 data of directive speech act found in Frozen 2 movie. That indicated types of directive speech acts those are command consist of 28 (76\%) utterances, order consist of $4(11 \%)$ utterances, and request consist of 5 (13\%) utterances. Based on the three dominant types of directive speech acts the researcher found command, order and request has a quite similar meaning. After analyzed the three dominant types the researcher found each meaning. Command is the utterance in which the speaker tells the listener to do something through an utterance that lacks a clear grammatical subject that purposed to demanding the hearer doing something and the sentence mostly using an exclaim mark. Order is an act that uttered by the speaker and the speaker has a rights or authority to get the listener to do something that must be done right away, then the sentences in order only contain a statement without contain command. Then request is used to ask something from the listener in a certain context that should be done with politeness way and structure about request mostly contains please, may, can, could and will you, so request mostly in the form of question because in request the speaker ask permission or agreement before telling the listener to do something. From the three dominant types of directive speech act between command, order and request that has a very specific difference and has same meaning to ask someone do something but the differences between the three dominant types of directive speech acts can be seen at the sentence structure in each sentence.

\section{REFERENCES}

Alexander. 2019. Expressive Speech Acts in the Hotel Transylvania Movie.

Thesis. Faculty of Foreign Languages Mahasaraswati University Denpasar.

Della, F. (2018). An Analysis of Dircective Speeech Acts By Searle Theory in "Sleeping Beauty" Movie Script. Journal of English Education and Teaching, 22. University of Bengkulu.

Feby Rosella Wijaya, J. H. (2019). An Analysis Of Directive Speech Acts In The Fault In Our Stars Movie Script. Journal of English Pedagogy, Linguistic, Literature and Teaching, 1. Suryakancana University.

Fita Nur Rahayu, M. B. (2018). Illocutionary Act in the Main Characters Utterances in Mirror Mirror Movie. Jurnal Ilmu Budaya, 175. English Department, Faculty of Cultural Sciences, Mulawarman University. 
Leech, Geoffrey. 1983. Principles Of Pragmatic. London: Longman Inc.

Margaretha, Tiwul. 2018. An Analysis Of Expressive Illocutionary Acts Found In The College Light Between Ocean Movie Script.Thesis. Faculty of Foreign Languages Mahasaraswati University Denpasar.

Sapir, Edward. 1921. An Introduction To The Study Of Speech. New York: Harcourt, Brace And Company.

Searle, John, R. 1979. Expression And Meaning Studies In The Theory Of Speech Act. New York: Cambridge University Press.

Yasa, Ari. 2020. An Analysis of Directives Illocutionary Act Found In The Movie Entitled Ride Along. 